\title{
Assessing resiliency and personal growth in a group of adolescents experiencing negative life events: The mediating role of emotional intelligence
}

\author{
Magdalena Kobylarczyk $k^{C, D, E, F}$, Nina Ogińska-Bulik ${ }^{A, B, E, F}$ \\ Department of Health Psychology Institute of Psychology, University of Lodz, Poland
}

\section{BACKGROUND}

The aim of the study was to examine the relationship between resiliency, emotional intelligence and personal growth in a group of youth, including the mediating role of emotional intelligence in the relationship between resiliency and personal growth.

\section{PARTICIPANTS AND PROCEDURE}

The results of 101 adolescents who have experienced a negative life event were analysed. The age of respondents ranged between 16 and 17 years $(M=16.49 ; S D=0.50)$. The Personal Growth Questionnaire, Resiliency Measurement Scale and Emotional Intelligence Questionnaire were used in the study.
RESULTS

The results of the analyses indicate that emotional intelligence is positively associated with personal growth and plays a mediating role in the relationship between resiliency and the occurrence of positive changes after experiencing negative life events, especially in terms of changes in relating to others and appreciation of life.

\section{CONCLUSIONS}

When searching for factors determining the occurrence of positive consequences of experienced life events, their direct or indirect impact should be taken into account.

KEY WORDS

personal growth; resiliency; emotional intelligence; mediation; adolescents

CORRESPONDing AUthor - Magdalena Kobylarczyk, Department of Health Psychology Institute of Psychology,

University of Lodz, Poland, e-mail: mkobylarczyk@uni.lodz.pl

AUthors' CONTRIBUtion - A: Study design - B: Data collection - C: Statistical analysis - D: Data interpretation .

E: Manuscript preparation · F: Literature search · G: Funds collection

TO CITE THIS ARTICLE - Kobylarczyk, M., \& Ogińska-Bulik, N. (2018). Assessing resiliency and personal growth in a group of adolescents experiencing negative life events: The mediating role of emotional intelligence. Current Issues

in Personality Psychology, 6(2), 91-101.

RECEIVED 13.11.2016 · REVIEWED 19.12.2016 · ACCEPTED 13.04.2017 · PUBLISHED 13.06.2017 


\section{BACKGROUND}

Traumatic events affect not only adults, but also children and younger people. A study conducted in the US found that about $11.00 \%$ of children aged up to 11 years had experienced trauma, and that figure rose to $43.00 \%$ when the group included children under 18 years of age (Eckes \& Radunovich, 2012).

Similar studies conducted on Polish groups aged between 14 and 18 years indicate that $72.00 \%$ of respondents had experienced negative life events in their lives (Ogińska-Bulik, 2012). The most common event is the loss of a loved one, followed by the occurrence of chronic or acute disease, and an accident or injury. It should be noted that in experiencing the death of a family member, parental divorce or separation from a loved one, many adolescents experience a situation which may not represent a direct threat to health or life, but may nevertheless entail negative effects classified as subclinical symptoms of traumatic stress. In a study by Copeland, Keeler, Angold, and Castello (2010), while $24.00 \%$ of children related experiencing stress, only $5.90 \%$ reported experiencing actual traumatic events. However, although many negative consequences are associated with such highly stressful life events, they may also be accompanied by the presence of positive changes, expressed in the form of post-traumatic growth.

\section{THE RELATIONSHIP OF RESILIENCY AND EMOTIONAL INTELLIGENCE WITH THE OCCURRENCE OF POSTTRAUMATIC POSITIVE CHANGES}

The phenomenon of post-traumatic growth is already quite well presented in the literature. It was originally defined as the collection of positive changes that occur as a result of attempts to cope with the consequences of traumatic events. These include changes in interpersonal relations, self-perception and philosophy of life (Tedeschi \& Calhoun, 1996, 2004).

Post-traumatic positive changes are also observed in children and adolescents (Alisic, van der Schoot, van Ginkel, \& Kleber, 2008; Cryder, Kilmer, Tedeschi, \& Calhoun, 2006), although few studies have been conducted in this age group so far. These changes are reflected mainly in greater psychological resistance and emotional maturity, a deeper understanding of personal values, purpose and meaning in life, as well as a greater appreciation of life itself, an improved ability to relate to others, and greater compassion and empathy (Salter \& Stallard, 2004; Meyerson, Grant, Smith-Carter, \& Kilmer, 2011). Available studies conducted among children and adolescents in Poland confirm the presence of positive changes as a result of experienced negative life events (Ogińska-Bulik, 2012, 2013 ).
Among the factors determining the occurrence of post-traumatic positive change highlighted by Meyerson et al. (2011) in their model of post-traumatic growth in children and adolescents, particular attention is placed on the significance of personal resources, especially resiliency and emotional intelligence. However, while the term resilience generally refers to the ability to effectively overcome a negative life event, Block and Block (1980) treat it as a relatively permanent disposition which determines the process of flexible adaptation to the constantly changing requirements of life (resiliency) - more specifically, a relatively permanent personality trait which can support the process of overcoming traumatic events and dealing with the problems of everyday life. Similarly, Fredrickson (2001), and Ogińska-Bulik and Juczyński $(2008,2011)$ regard resiliency as a relatively permanent individual resource that is activated mainly as a result of a person experiencing serious difficulties or threats.

Resiliency promotes perseverance and flexible adaptation to the requirements of life, allows remedial action to be taken in difficult situations and increases tolerance of negative emotions and failures (OgińskaBulik \& Juczyński, 2008, 2011). Resilient children reveal a higher sense of meaningfulness in the actions they take, a positive attitude to life, a higher level of autonomy and self-confidence, and higher levels of skills that are necessary in everyday functioning (Klohnen, 1996; Robins, John, Caspi, Moffitt, \& Stouthamer-Loeber, 1996).

The results of research conducted in Poland in groups of adults suggests the existence of a positive relationship between resiliency and the appearance of positive changes after experiencing trauma. This has been demonstrated in groups of people who had lost someone close (Ogińska-Bulik, 2014), or who had undergone cardiac surgery (Ogińska-Bulik \& Juczyński, 2012). This relationship appears to be confirmed by available data on children and adolescents. In studies of teenagers who had experienced different kinds of negative life events, resiliency was positively associated with post-traumatic growth (Levine, Laufer, Stein, Hamma-Raz, \& Solomon, 2009; Ogińska-Bulik, 2012, 2013; Ogińska-Bulik \& Kobylarczyk, 2015b).

However, the studies, including those based on the emergency services (Ogińska-Bulik, 2015a; Ogińska-Bulik \& Kobylarczyk, 2015a, 2016), do not confirm the presence of a direct relationship between resiliency and the occurrence of post-traumatic positive changes. This indicates that the role of resiliency in growth after trauma is ambiguous, and that the relationship can be mediated by other variables, such as emotional intelligence and other personal resources.

Emotional intelligence is defined as the ability of individuals to perceive, evaluate and express emotions and excitation, to use them for promoting cog- 
nitive activity, and to control their own emotions and those of other people. Salovey and Mayer (1990), who conceived the concept, define three groups of components in the structure of emotional intelligence. The first consists of four types of abilities: two related to the evaluation and expression of the individual's own emotions, and two with assessing those of other people. The second comprises the ability to regulate the emotions of the individual and other people. The third group concerns the ability to use emotions to influence flexibility, creative thinking, flexibility of attention and motivation for action.

Research conducted by Block (1995, not published, original Goleman, 1997) indicates that persons characterized by a high level of emotional intelligence are more willing to devote their time and energy for the benefit of other people, are more likely to take responsibility, do not tend to worry, are more open and socially oriented and environmentally conscious; they are satisfied with themselves, rarely experience anxiety and guilt, and their emotional life is rich. Emotionally intelligent people are well aware of their emotions and are in control of them, they can read the emotions of others and appropriately refer to them, usually achieve success and are able to do well in professional situations. They are well-liked and respected by others.

When treated as a property of personality, emotional intelligence is positively associated with resiliency, as demonstrated by research conducted among Japanese students (Nozaki, 2012), US citizens (Armstrong, Galligan, \& Critchney, 2011), and undergraduate middle-eastern university students (Schneider, Lyons, \& Khazon, 2013). A few studies also note the presence of a positive relationship between emotional intelligence and post-traumatic growth $(\mathrm{Li}, \mathrm{Cao}$, Cao, \& Liu, 2014; Nozaki, 2012; Linley, Felus, Gillett, \& Joseph, 2011; Salsman, 2006). Emotional intelligence can also play a mediating role: it was observed in the relationship between mindfulness and subjective well-being (Schutte \& Malouff, 2011), parental attitudes and subsequent behaviour adjustment in adolescents (Alegre \& Benson, 2010), personality and health of a group of students (Johnson, Batley, \& Holdworth, 2009), and family communication patterns and restraint (Keaten \& Kelly 2008).

Hence, it can be assumed that a positive relationship exists between resiliency and personal growth, and that this can be mediated by emotional intelligence. In addition, little research has been conducted in this area, especially involving the variable emotional intelligence.

Emotional intelligence was chosen as a mediator in the relationship between resiliency and personal growth because it can be developed during life, while the resiliency of this approach is regarded as a relatively stable set of personality traits.

\section{AIMS, CONTEXT, STUDY QUESTIONS}

The aim of the study was to examine the relationship between resiliency, emotional intelligence and personal growth in a group of adolescents. The study also aimed to establish the mediating role of emotional intelligence in the relationship between resiliency and personal growth. The following research questions were addressed:

- To what extent do positive changes in the form of personal growth appear in adolescents who have experienced various negative life events?

- How does the severity of positive changes depend on the sex or age of the respondents, or the time since the experienced event?

- What relationship is there between resiliency, emotional intelligence and personal growth?

- How does emotional intelligence mediate the relationship between resiliency and personal growth in the group of adolescents?

\section{PARTICIPANTS AND PROCEDURE}

The study included a group of 101 adolescents attending secondary schools in Poland. The criterion for selection of adolescents to study was the experience of a traumatic event. The purpose of the study was explained to the participants and they were informed of its anonymous nature. The study was conducted in hard copy form, at schools during the lessons ${ }^{1}$. It was approved by the appropriate Commission of Bioethics. Of the participants, $51.00 \%$ were female and the age of adolescents ranged from 16 to 17 years $(M=$ 16.49; $S D=0.50)$.

\section{MEASURES}

Three instruments were used in the study: the KOW-27 Personality Growth Questionnaire, the SPP-18 Resiliency Measurement Scale to measure resiliency in children and adolescents, and the INTE Emotional Intelligence Questionnaire.

The KOW-27 Personal Growth Questionnaire developed by Ogińska-Bulik (2013) consists of 27 statements regarding the presence of positive changes resulting from negative life events (e.g. "I feel more confident"). The conducted factor analysis (Varimax with orthogonal rotation) revealed three factors: Factor 1 - Changes in self-perception, Factor 2 - Appreciation of life and Factor 3 - Changes in relating to others (all the nine positions). To determine the level of changes, temporary standards expressed on a sten scale were designed, where a score of 1-4 indicated a low level, 5-6 a medium level and 7-10 a high level. According to the instructions respondents first indicate the event with the greatest impact on them and 
the time since the event, and then assess the positive changes resulting from it using a four-step scale from 0 (never experienced this change) to 3 (experienced that change to a large extent). The reliability of the questionnaire is high, measured by a Cronbach's $\alpha$ coefficient of .94 .

The SPP-18 Resiliency Measurement Scale, by Ogińska-Bulik and Juczyński (2011), was developed for children and adolescents aged 12-19. The tool consists of 18 items, assessed on a 5-point scale, where 0 stands for strongly disagree, 1 for somewhat disagree, 2 for neither agree nor disagree, 3 for somewhat agree, and 4 for strongly agree (e.g. "I can cope even with the greatest difficulties"). Higher total scores indicated higher levels of resiliency. The raw results were recalculated to sten scores. The SPP-18 allows a general score to be calculated, as well as scores for the four factors constituting resiliency: Optimistic attitude and energy; Persistence and determination in action; Sense of humour and openness to new experiences; Personal competences and tolerance for negative affect. The tool is characterised by good psychometric properties, with a Cronbach's $\alpha$ of .82 for the main score and the subscales ranging from .76 to .87 . The test-retest reliability of the tool, established at a 6-week time interval, is .78.

The INTE Emotional Intelligence Questionnaire by Schutte, Malouff, Simunek, Hollander, and McKenley (2002) is used to measure emotional intelligence, which is understood as the ability of the participants to recognize, understand, control and effectively manage their own emotions and those of other people. The Polish adaptation of the INTE was prepared by Ciechanowicz, Jaworowska and Matczak (Jaworowska \& Matczak, 2001). The questionnaire is designed to test young people and adults. It consists of 33 items, whose truthfulness in relation to self-evaluate is tested on a five-point scale: 1 - strongly disagree, 2 - dis- agree, 3 - hard to say, 4 - disagree, 5 - strongly agree (e.g. "I know when I can talk to others about my personal problems"). The scale has satisfactory internal compliance and absolute stability. Cronbach's $\alpha$ coefficients are within the range of .83 to .87 .

\section{RESULTS}

As the distribution of the analysed variables was normal, parametric tests were used. Student's $t$-test, $F$-test and ANOVA were used to determine the difference between the means. Pearson R correlations were used to determine the relationship between variables. Mediation analysis was carried out according to Preacher and Hayes (2008), to verify whether emotional intelligence acts as a mediator in the relationship between resiliency and personal growth. The macro Indirect was used by drawing 5000 bootstrap samples.

The mean personal growth of respondents (Table 1 ) corresponds to a value of 5 sten; the result is located in the average values. Based on standards developed for the KOW-27 (Ogińska-Bulik, 2013), it can be indicated that 34 of the respondents $(33.70 \%)$ demonstrated a low level, 47 (46.50\%) medium and 20 (19.80\%) a high level of personal growth. To determine which areas demonstrated the greatest changes, the mean scores of the individual KOW-27 factors were divided by the number for their own findings. Significantly greater changes were given for Factor 2 - Appreciation of life $(M=1.78)$ than for Factor 1 - Changes in self-perception $(M=1.42)$ and Factor 3 - Changes in relating to others $(M=1.44)(p<.01, t=7.17)$.

No difference was observed in the severity of positive changes resulting from experienced events in the study group of teens with regard to the sex of the participant (boys: $M=40.08, S D=14.46$ girls: $M=41.08, S D=12.44, F=.19, d f=1, p=.600)$ or any

Table 1

Mean values of personal growth, emotional intelligence and resiliency

\begin{tabular}{lcc}
\hline & $M$ & $S D$ \\
\hline Personal growth - general score & 41.92 & 17.32 \\
F. 1. Self-perception & 12.83 & 6.60 \\
F. 2. Appreciation of life & 16.01 & 6.27 \\
F. 3. Changes in relating to others & 13.02 & 6.98 \\
Emotional intelligence & 118.50 & 14.93 \\
Resiliency - general score & 46.00 & 12.88 \\
F. 1. Optimistic attitude and energy & 12.32 & 4.09 \\
F. 2. Persistence and determination in action & 13.07 & 3.94 \\
F. 3. Sense of humour and openness to new experiences & 10.98 & 3.24 \\
F. 4. Personal competencies and tolerance of negative affect & 9.63 & 3.68 \\
\hline
\end{tabular}

Note. $M$ - mean; $S D$ - standard deviation. 
of the factors. The single most common negative life event was the death of a loved one $(37.60 \%, N=38)$, which was followed by divorce of parents $(17.80 \%$, $N=18)$, serious illness of a family member $(9.90 \%$, $N=10)$, parting with a loved one $(5.90 \%, N=6)$, experience of violence $(5.90 \%, N=6)$, accident or injury $(5.00 \%, N=5)$, serious financial family difficulties $(4.00 \%, N=4)$, being a witness to a crime or accident $(3.00 \%, N=3)$, suffering chronic or acute disease $(3.00 \%$, $N=3)$, or experiencing violent crime $(1.00 \%, N=1)$. Other events not included in the manual questionnaire events constituted $3 \%$ of the responses. No relationship was found between the type of negative life situation and the severity of personal growth for young people in the study group $(F=1.91, p=.390, d f=13)$.

The relationship between time elapsed since the event and the level of personal growth was also examined. In $26.70 \%$ of the respondents, the experienced event had taken place within the previous year before the study, $10.90 \%$ in the last two years, $10.90 \%$ within three years and $51.5 \%$ within a period of more than three years. The time passed since the event did not affect $(F=.19, p=.900, d f=3)$ the level of personal growth $(1 . M=44.36, S D=16.18,2 . M=41.62$, $S D=15.17,3 . M=32.91 ; S D=22.31,4 . M=44.42$, $S D=15.52$ ) or the severity of any of the KOW-27 factors.

The level of resiliency identified in the study could be regarded as average ( 5 sten). However, the respondents obtained higher scores for Factor 1 (Optimistic attitude and energy $-M=12.32 ; S D=4.09)$ and Factor 2 (Persistence and determination in action $M=13.07$; $S D=3.94$ ) than Factor 3 (A sense of humour and openness to new experiences $-M=10.98$; $S D=3.24$ ) and Factor 4 (Personal competencies and tolerance to negative affect $-M=9.63 ; S D=3.68$; $p<.05)$. The female respondents obtained a higher mean score for emotional intelligence $(M=113.22$, $S D=16.38$ ), corresponding to a value of 4 sten, than

Table 2

Correlation coefficients between resiliency and emotional intelligence, and personal growth

\begin{tabular}{lcccc}
\hline Variables & $\begin{array}{c}\text { Personal } \\
\text { growth } \\
\text { general }\end{array}$ & $\begin{array}{c}\text { F. 1 } \\
\text { Changes in } \\
\text { self-perception }\end{array}$ & $\begin{array}{c}\text { F. 2 } \\
\text { Greater } \\
\text { appreciation } \\
\text { of life }\end{array}$ & $\begin{array}{c}\text { F. 3 } \\
\text { Changes in } \\
\text { relating to } \\
\text { others }\end{array}$ \\
\hline $\begin{array}{l}\text { Resiliency - general score } \\
- \text { Optimistic attitude and energy }\end{array}$ & .123 & .162 & $.297^{* *}$ & -.091 \\
$\begin{array}{l}\text { Persistence and determination } \\
\text { in action }\end{array}$ & .126 & .058 & $.248^{*}$ & -.053 \\
$-\begin{array}{l}\text { Sense of humour and openness } \\
\text { to new experiences }\end{array}$ & .037 & .188 & $.288^{* *}$ & -.120 \\
$-\begin{array}{l}\text { Personal competencies and } \\
\text { tolerance of negative affect }\end{array}$ & .094 & .087 & .158 & -.072 \\
\begin{tabular}{l} 
Emotional intelligence \\
\hline
\end{tabular}
\end{tabular}

boys $(M=123.90, S D=11.06)$, corresponding to 5 sten. In both cases, as they fell in the range 4-7 sten, the results can be regarded as average (Jaworowska \& Matczak, 2001).

The next part of the study addressed the relationship between personal resources, in the form of resiliency and emotional intelligence, and the personal growth of adolescents who had experienced a negative life event. The obtained correlation coefficients are presented in Table 2.

The results indicate a positive relationship between emotional intelligence and personal growth (general result). Factor 2 of the KOW-27 (Appreciation of life) was found to be positively associated with emotional intelligence and resiliency (general score, and factor 1 and 2). The other two factors associated with personal growth are not significantly related to resiliency or emotional intelligence.

The next step used mediation analyses based on a bootstrapping procedure where 5000 bootstrap samples were drawn. This method offers more benefits than the more commonly used Sobel test. It has greater explanatory power, does not require assumptions about the normality of the distribution of variables and allows analyses to be conducted on relatively small samples. Mediation analysis allows a more complex structure model to be set, in which an independent variable (predictor) (in this case, resiliency) is associated with the dependent variable (personal growth), through a third variable, acting as mediator (emotional intelligence). A mediating effect is thought to occur when the mediating variable increases the predictive properties of the independent variable on the dependent variable (Preacher \& Hayes, 2008).

The first step was to analyse the relationship between the general result of the resiliency and the general result of personal growth in the group of
Note. ${ }^{*} p<0.05 .{ }^{* *} p<0.01$. 
teenagers. Emotional intelligence was introduced as a mediator. The results do not indicate the presence of any direct relationship between a dependent and independent variable (Figure 1). By contrast, the interaction between resiliency and emotional intelligence will result in higher levels of personal growth. It can therefore be assumed that young people characterized only by a high level of resiliency will less frequently experience positive changes after trauma than those who are resilient and possess a well-developed emotional intelligence.

The next step of the analysis was the introduction of subsequent factors of personal growth in place of the dependent variable, leaving resiliency as an independent variable and emotional intelligence as a mediator. It was found that two factors of personal growth, Appreciation of life and Changes in relating to others, had an indirect effect on the form of mediation (Figures 2 and 3). Analysing the obtained results, it can be concluded that resilient young people with well-developed emotional intelligence will appreciate life more and reveal greater changes in relating to others than a group of young people just characterized by a high level of resiliency. This relationship was not observed in the case of Self-perception.

The final step of the analysis was the replacement of independent variable subsequent factors of resiliency and leaving the general level of personal growth. Emotional intelligence was introduced as a potential mediator. The results of the analysis indicate that for all four factors of resiliency, emotional intelligence plays a mediating role (Figures 4-7).

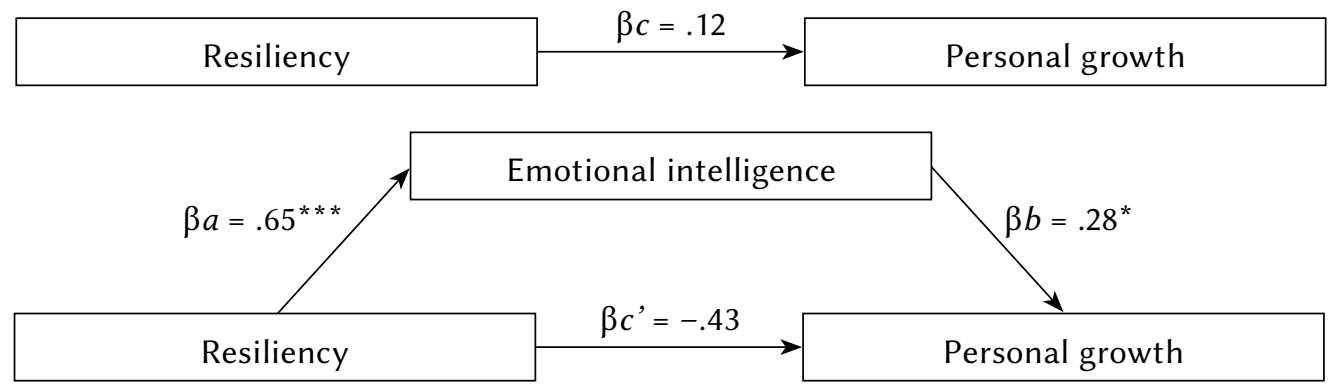

Note. ${ }^{*} p<.05 .{ }^{* * *} p<.001$

Figure 1. Model of the relationship between resiliency, emotional intelligence and personal growth of the examined adolescents.

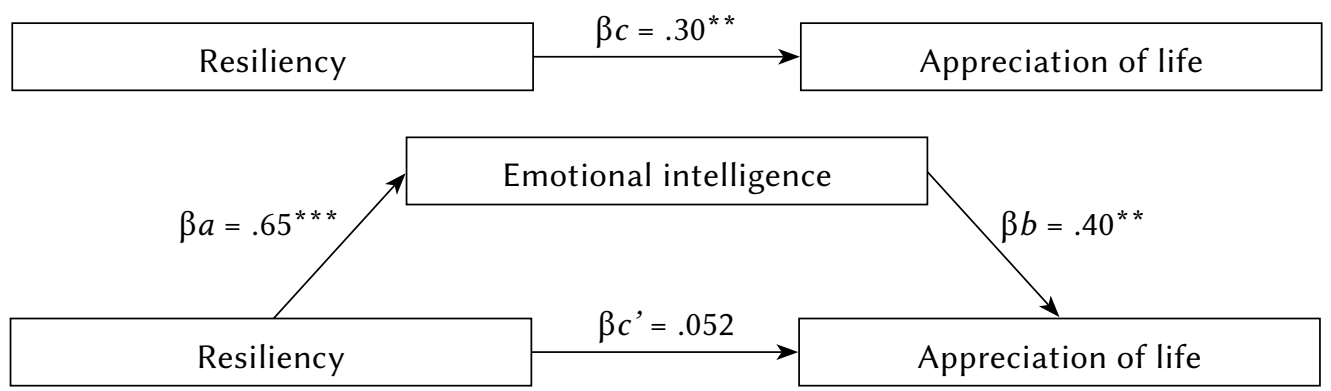

Note. ${ }^{* *} p<.01 .{ }^{* * *} p<.001$.

Figure 2. Model of the relationship between resiliency, emotional intelligence and changes in appreciation of life.

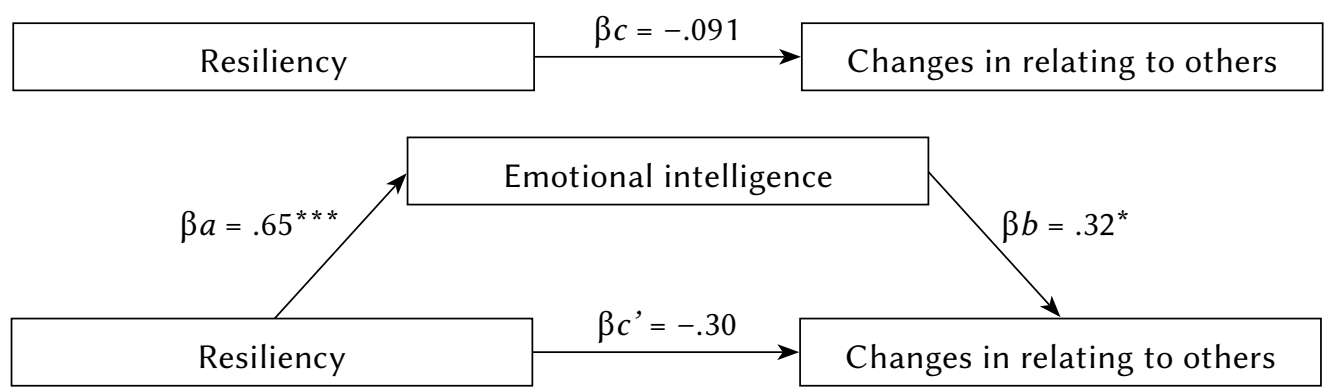

Note. ${ }^{*} p<0.05 .{ }^{* * *} p<.001$.

Figure 3. Model of the relationship between resiliency, emotional intelligence and changes in relating to others. 


\begin{tabular}{|l|l|l|}
\hline Optimistic attitude and energy & $\beta c=.08$ & Personal growth \\
\cline { 2 - 3 } & &
\end{tabular}

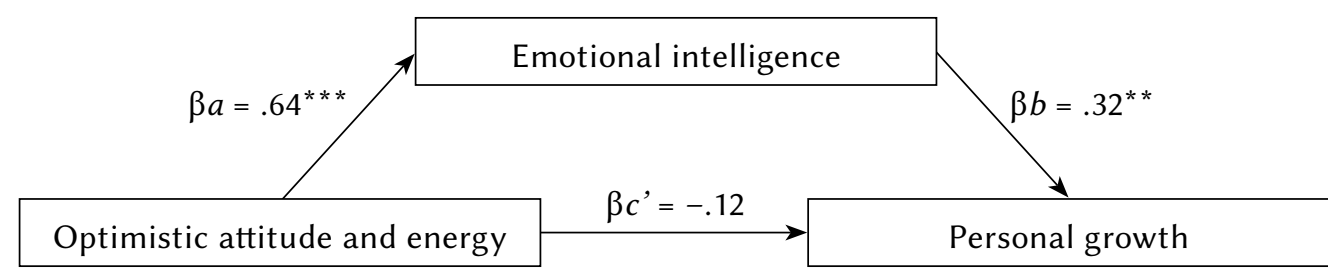

Note. ${ }^{* *} p<.01 .{ }^{* * *} p<.001$.

Figure 4. Model of the relationship between optimistic attitude and energy, emotional intelligence and personal growth.

\begin{tabular}{|c|c|c|}
\hline Persistence and determination in action & pe & Personal growth \\
\hline
\end{tabular}

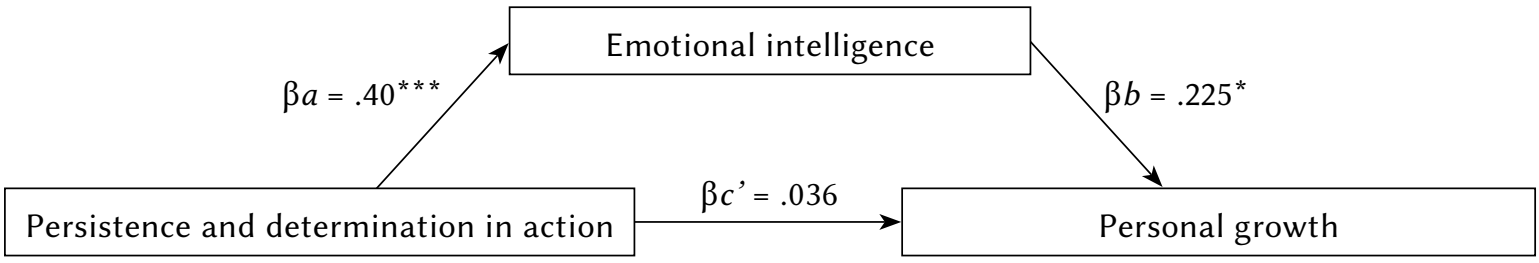

Note. ${ }^{*} p<.05 .{ }^{* * *} p<.001$.

Figure 5. Model of the relationship between persistence and determination in action, emotional intelligence and personal growth.

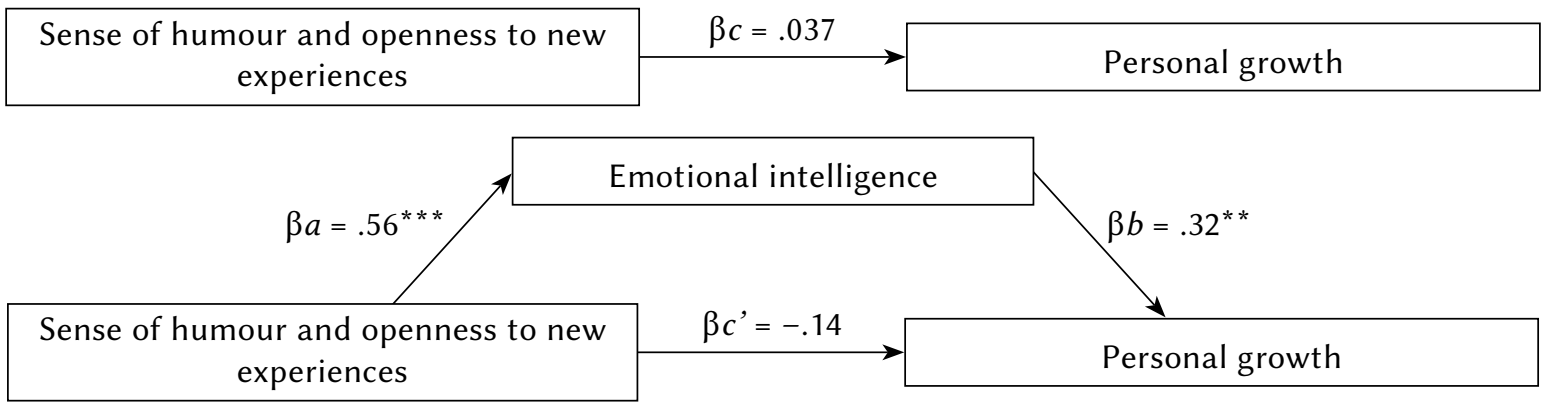

Note. ${ }^{* *} p<.01 .{ }^{* *} p<.001$.

Figure 6. Model of the relationship between sense of humour and openness to new experiences, emotional intelligence and personal growth.

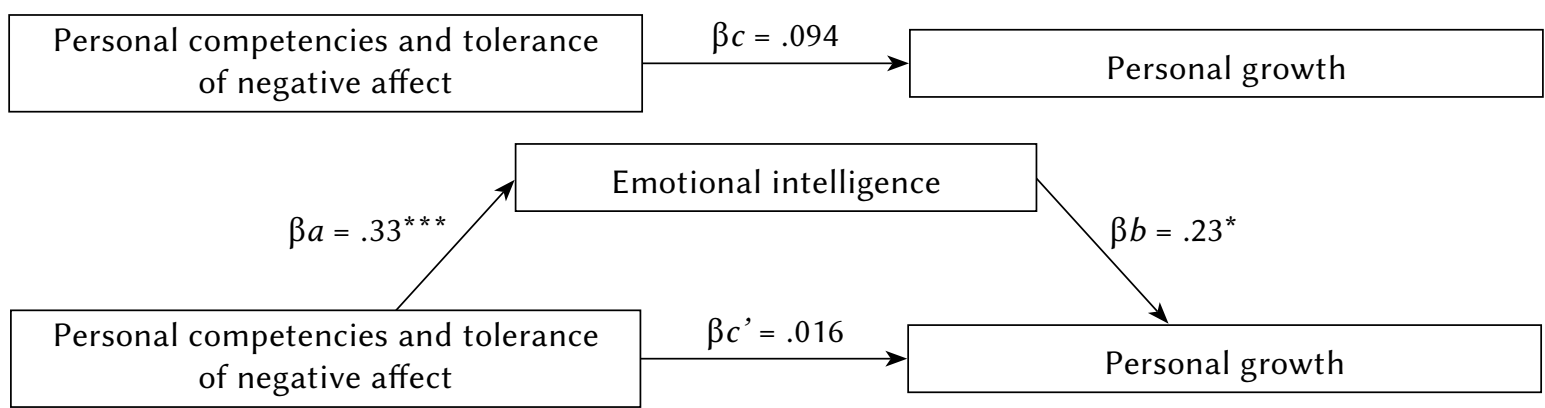

Note. ${ }^{*} p<.05 .{ }^{* * *} p<.001$.

Figure 7. Model of the relationship between personal competencies and tolerance of negative affect, emotional intelligence and personal growth. 
Therefore, a person characterized by an optimistic attitude and energy, persistence and determination in action, sense of humour and openness to new experiences and/or personal competences, tolerance of negative affect and a well-developed emotional intelligence, may be more likely to experience positive effects following critical events.

\section{DISCUSSION}

The results of the study indicate that for young people, experiencing negative life events may be a source of positive changes. Of the respondents, $33.70 \%$ revealed high levels of personal growth, and $46.50 \%$ moderate. These are higher values than those observed by Milam, Ritt-Olson and Unger (2004) in a group of teenagers who had experienced various negative life events, $30 \%$ of whom revealed at least a moderate level of positive changes. Greater changes were related to Appreciation of life than Self-perception and Changes in relating to others. A similar result was obtained in a group of adolescents who had been victims of road accidents (Salter \& Stallard, 2004).

The sex of the respondent, type of experienced event or time since its occurrence did not influence the level of observed changes. The most common single event experienced by those examined was the death of a loved one, but the persons who have experienced the death of someone close did not differ in the level of personal growth of people who have experienced other events.

However, within the group of teenagers, fewer respondents demonstrated a high level of personal growth than adults examined in previous studies. In a group of women with oncological disease, positive changes were observed in $50.00 \%$ of respondents (Ogińska-Bulik, 2010). The lower severity of changes observed in the group of teenage study participants may be associated with the developmental period: during this period, characteristic of adolescence, teenagers experience strong negative emotions (regardless of experienced life events), and are prone to worrying, exaggerating the importance of experiences and their negative affect, and tend to focus on the present. These tendencies may become muted by the emergence of positive changes resulting from experienced life events.

The examined adolescents present an average level of resiliency which, in turn, is positively related to the occurrence of personal growth. This relationship is confirmed by studies of young people experiencing feelings of horror associated with war and adults, for example, civilians and soldiers involved in the war in Lebanon (Levine, 2009). Also, a positive relationship between resiliency and post-traumatic growth has been observed among adults who have experienced the death of someone close (Ogińska-Bulik 2014, 2015a).
Our findings indicate that emotional intelligence is positively associated with personal growth. As expected, it also acts as a mediator in the relationship between resiliency and personal growth in the examined group of young people experiencing negative life events, especially in terms of relating to others and appreciation of life. This corresponds to a study by Nozaki (2012), who notes the presence of a positive relationship between resiliency and emotional intelligence in a group of Japanese students. On the other hand, Linley et al. (2011) found emotional intelligence to be positively associated with post-traumatic growth among women, but not men.

Available studies confirm that emotional intelligence may play a mediating role. Such results were obtained in the studies by Schutte and Malouff (2011) in which the relationship between mindfulness and subjective well-being was mediated by emotional intelligence. Also in studies by Alegre and Benson (2010) emotional intelligence was found to be a mediator between parental attitudes and subsequent behaviour adjustment in adolescents. The same mediating role of this variable was revealed between personality and health of a group of students (Johnson, Batley, \& Holdworth, 2009) and family communication patterns and restraint (Keaten \& Kelly 2008).

The present study suggests that adolescents possessing personal resources, especially emotional intelligence, can reap the benefits of experienced negative life events. The role of resiliency in the process of the emergence of positive changes, revealed in the form of personal growth, appears to be smaller. Its beneficial effect on the occurrence of these changes requires a high level of emotional intelligence.

The conducted analysis of mediation did not reveal any direct relationship between resiliency and personal growth in the studied group of young people who had experienced various negative life events. This may be associated with the ambiguous nature of the term resiliency, concerning either a process or a personality trait, and the unclear nature of the relationship between resiliency and post-traumatic growth. Some authors equate these two concepts (Westphal \& Bonanno, 2007), while others assume that the growth after trauma is a form of resiliency (Johnson et al. 2007), and others that post-traumatic growth is more significant than resiliency and plays an overriding role (Lepore \& Revenson, 2006). Tedeschi and Calhoun (1996) clearly differentiate these two concepts, stressing that the growth after trauma is due to the transformation and can appear suddenly and unexpectedly. In contrast, resiliency, a property of personality, is relatively constant and develops as a result of the accumulation of multiple experiences by the individual. Tedeschi and Calhoun emphasize that resilient people may not experience growth because a traumatic event may not represent a sufficiently strong challenge for them. As demon- 
strated by a previous study of workers in the emergency services, resiliency seems to play a greater role in preventing the negative effects of the experienced trauma than fostering the growth of positive post-traumatic changes, as although the study findings indicated that resiliency was a predictor of post-traumatic stress symptoms, it was not associated with growth following traumatic events (Ogińska-Bulik, 2015b). A revised model of posttraumatic growth presented by Tedeschi and Calhoun (1996, 2004) highlights the importance to properties of pretrauma personality, cognitive activity and applied coping strategies in the process of positive posttraumatic changes.

\section{LIMITATIONS}

This research does have certain limitations. The negative effects of experienced events, for example in the form of post-traumatic stress symptoms, were not analysed. In addition, the examined adolescents experienced a range of varied negative life events, which could have affected the assessment of the perceived positive changes to varying degrees. These changes were evaluated using a self-reporting questionnaire, which could influence the results. Furthermore, some of the changes, such as changes in philosophy or self-perception, may occur in young people as a result of the implementation of task development, and not of any experienced trauma. In contrast to the developmental changes resulting from the course of life, changes that stimulate personal growth are of an individual nature; it is not easy for a respondent to distinguish changes resulting from real life experience from those which are part of the natural development of the individual. Finally, it should also be noted that the study is of a cross-sectional nature, making it impossible to unequivocally establish the existence of causal relationships.

Nevertheless, despite their limitations, our findings add new depth to the relationship between the resources of the individual and the positive effects of negative life events. They can provide inspiration for further studies, in which it would be worthwhile to consider the role of cognitive involvement of people experiencing trauma, and more importantly, the importance of rumination. The presented issues may also be relevant for clinical practice, particularly with regard to crisis intervention and prevention programmes, during which attention should be paid to developing the skills of processing the suffered trauma and the development of competence in coping with traumatic experiences, including fostering resiliency and emotional intelligence. Our findings also reinforce the fact that posttraumatic growth is an opportunity to build resiliency and cope better with the challenges of life that may occur in the future.

\section{CONCLUSIONS}

1. Personal resources (resiliency, emotional intelligence) play an important role in occurrence of positive changes after trauma.

2. Emotional intelligence can both directly and indirectly affect personal growth.

3. The importance of practice - resource development increases the chances of a positive change after experiencing a critical event.

\section{EDNOTES}

1 Study by an MA seminar participant, Paulina Lipińska.

\section{RefERENCES}

Alegre, A., \& Benson, M. J. (2010). Parental behaviors and adolescent adjustment: Mediation via $\mathrm{Ad}$ olescent Trait Emotional Intelligence. Individual Differences Research, 8, 83-96.

Alisic, E., van der Schoot, T. A., van Ginkel, J. R., \& Kleber, R. J. (2008). Looking Beyond Posttraumatic Stress Disorder in Children: Posttraumatic Stress Reaction, Posttrauamtic Growth, and Quality of Life in a General Population Sample. Journal of Clinical Psychiatry, 69, 1455-1461.

Armstrong, A. R., Galligan, R. F., \& Critchley, Ch. R. (2011). Emotional intelligence and psychological resilience to negative life events. Personality and Individual Differences, 51, 331-336.

Block, J. H., \& Block, J. (1980). The role of ego-control and ego-resiliency in the origination of behavior. In W. A. Collings (Ed.). The Minnesota Symposia on Child Psychology (pp. 39-101). Hillsdale, New Jersey: Lawrence Erlbaum Associates.

Copeland, W., Keeler, G., Angold, A. J., \& Castello, E. J. (2010). Posttraumatic stress without trauma in children. American Journal of Psychiatry, 167, 1059-1065.

Cryder, C. H., Kilmer, R. P., Tedeschi, R. G., \& Calhoun, L. G. (2006). An Exploratory Study of Posttraumatic Growth in Children Following a Natural Disaster. American Journal of Orthopsychiatry, 76, 65-69.

Eckes, A., \& Radunovich, H. L. (2012). Trauma and Adolescents. Publication \#FCS2280, University of Florida IFAS Extension, 1-5. Retrieved 15.05.2015.

Fredrickson, B. (2001). The role of positive emotions in positive psychology: The broaden-and build theory of positive emotions. American Psychologist, 56, 218-226.

Goleman, D. (1997). Inteligencja emocjonalna [Emotional intelligence]. Poznań: Wydawnictwo Media Rodzina. 
Jaworowska, A., \& Matczak, A. (2001). Kwestionariusz inteligencji emocjonalnej [Emotional intelligence questionnarie]. Warszawa: Pracownia Testów Psychologicznych PTP.

Johnson, S. J., Batley, M., \& Holdsworth, L. (2009). Personality and health: The mediating role of Trait Emotional Intelligence and Work Locus of Control. Personality and Individual Differences, 47, 470-475.

Johnson, R. J., Hobfoll,S.E., Hall, B. J., Canetti-Nisim, D., Galea, S., \& Palmieri, P. A. (2007). Posttraumatic growth: Action and reaction. Applied Psychology, 56, 428-436.

Keaten, J., \& Kelly, L. (2008). Emotional Intelligence as a Mediator of Family Communication Patterns and Reticence. Communication Reports, 21, 104-116.

Klohnen, E. C. (1996). Conceptual analysis and measurement of the construct of ego-resiliency. Journal of Personality and Social Psychology, 70, 1067-1079.

Lepore, S. J., \& Revenson, T. A. (2006). Resiliency and posttraumatic growth recovery, resistance and reconfiguration. In L. G. Calhoun \& R. G. Tedeschi (Eds.), Handbook of posttraumatic growth: Research and practice (pp. 264-290). Mahwah, New Jersey: Lawrence Erlbaum Publishers.

Levine, S. Z., Laufer, A., Stein, E., Hamma-Raz, Y., \& Solomon, Z. (2009). Examining the relationship between resilience and posttraumatic growth. Journal of Traumatic Stress, 22, 282-286.

Li, Y., Cao, F., Cao, D., \& Liu, J. (2015). Nursing students' post-traumatic growth, emotional intelligence and psychological resilience. Journal of Psychiatric \& Mental Health Nursing, 22, 326-332.

Linley, P. A., Felus, A., Gillett, R., \& Joseph, S. (2011). Emotional Expression and Growth Following Adversity: Emotional Expression Mediates Subjective Distress and is Moderated by Emotional Intelligence. Journal of Loss and Trauma, 16, 387-401.

Meyerson, D., Grant, K., Smith-Carter, J., \& Kilmer, R. (2011). Posttraumatic growth among children and adolescents. Clinical Psychology Review, 31, 949-964.

Milam, J., Ritt-Olson, A., \& Unger, J. (2004). Posttraumatic growth among adolescents. Journal of Adolescent Research, 19, 192-204.

Nozaki, Y. (2012). The Relationships among Resilience and Posttraumatic Growth and Emotional Intelligence Based on a Distinction between the Self and Others Domains. Japanese Journal of Personality, 3, 179-192.

Ogińska-Bulik, N. (2010). Potraumatyczny rozwój w chorobie nowotworowej - rola prężności [Posttraumatic growth in cancer disease - the role of resiliency]. Polskie Forum Psychologiczne, 15, 125-139.
Ogińska-Bulik, N. (2012). Prężność a potraumatyczny rozwój u młodzieży [Resiliency and post-traumatic growth in adolescents] In N. Ogińska-Bulik \& J. Miniszewska (Eds.), Zdrowie w cyklu życia cztowieka [Health in the human life cycle] (pp. 7385). Łódź: Wydawnictwo Uniwersytetu Łódzkiego.

Ogińska-Bulik, N. (2013). Pozytywne skutki doświadczanych zdarzeń o charakterze traumatycznym u dzieci i młodzieży. Kwestionariusz Osobowego Wzrostu - KOW-27 (wersja D/M i R/O) [Positive outcomes of experienced traumatic events in children and youth. The Personal Growth Questionnaire - KOW-27 (version D/M and R/O)]. Polskie Forum Psychologiczne, 18, 93-111.

Ogińska-Bulik, N. (2014). Posttraumatic growth following the death of someone close - the role of temperament and resiliency. Polish Journal of Applied Psychology, 3, 29-44.

Ogińska-Bulik, N. (2015a). The relationship between resiliency and posttraumatic growth following the death of someone close. Journal of Death and Dying, 17, 1-12.

Ogińska-Bulik, N. (2015b). Dwa oblicza traumy. Negatywne i pozytywne skutki zdarzeń traumatycznych u pracowników stużb ratowniczych [The two faces of the trauma - negative and positive effects of traumatic events in emergency service workers]. Warszawa: Wydawnictwo Difin.

Ogińska-Bulik, N., \& Juczyński Z. (2008). Skala do pomiaru prężności - SPP-25 [The scale of measurement of resilience - SPP-25]. Nowiny Psychologiczne, 3, 39-56.

Ogińska-Bulik, N., \& Juczyński, Z. (2010). Potraumatyczny wzrost - charakterystyka i pomiar [Posttraumatic growth - characteristic and measurement]. Psychiatria, 7, 129-142.

Ogińska-Bulik, N., \& Juczyński, Z. (2011). Prężność u dzieci i młodzieży - charakterystyka i pomiar [Resiliency in children and adolescents - characteristics and measurement]. Polskie Forum Psychologiczne, 1, 7-28.

Ogińska-Bulik, N., \& Juczyński, Z. (2012). Prężność jako wyznacznik pozytywnych i negatywnych konsekwencji doświadczonej sytuacji traumatycznej [Resiliency as a determinant of positive and negative consequences experienced traumatic situation]. Polskie Forum Psychologiczne, 17, 395-410.

Ogińska-Bulik, N., \& Kobylarczyk, M. (2015a). Relation between resiliency and posttraumatic growth in a group of paramedics - the mediating role of coping strategies. International Journal of Occupational Medicine and Health, 28, 1-13.

Ogińska-Bulik, N., \& Kobylarczyk, M. (2015b). Resiliency and social support as factors promoting the process of resilience in adolescents - wards of children's homes. Health Psychology Report, 3, 1-10.

Ogińska-Bulik, N., \& Kobylarczyk, M. (2016). Association between resiliency and posttraumatic 
growth in firefighters: the role of stress appraisal. Journal of Occupational Safety and Medicine, 22, 40-48.

Preacher, K., \& Hayes, A. F. (2008). Asymptotic and resampling strategies for assessing and comparing indirect effects in multiple mediator models. Behavior Research Methods, 40, 879-891.

Robins, R. W., John, O. P., Caspi, A., Moffitt, T. E., \& Stouthamer-Loeber, M. (1996). Resilient, overcontrolled, and undercontrolled boys. Three replicable personality types. Journal of Personality and Social Psychology, 70, 157-171.

Salsman, J. M. (2006). Posttraumatic growth and PTSD symptomatology among colorectal cancer survivors: The impact of emotional expression and cognitive processing. University of Kentycky Doctoral Disserations. Retrieved from http://uknowledge.uky.edu/cgi/viewcontent.cgi? article $=1408 \&-$ context=gradschool_diss

Salovey, P., \& Mayer, J. D. (1990). Emotional intelligence. Imagination, Cognition, and Personality, 9, 185-211.

Salovey, P., Mayer, J. D., \& Caruso, D. (2004). Pozytywna psychologia inteligencji emocjonalnej [Positive psychology of emotional intelligence]. In J. Czapiński (Ed.), Psychologia pozytywna [Positive psychology] (pp. 380-398). Warszawa: Wydawnictwo Naukowe PWN.

Salter, E., \& Stallard, P. (2004). Posttraumatic growth in child survivors of a road traffic accident. Journal of Traumatic Stress, 17, 335-340.

Schneider, T. R., Lyons, J. B., \& Khazon, S. (2013). Emotional intelligence and resilience. Personality and Individual Differences, 55, 909-914.

Schutte, N.S., Malouff,J.M.,Simunek, M., Hollander,S., \& McKenley, J. (2002). Characteristic emotional intelligence and emotional well-being. Cognition and Emotion, 16, 769-786.

Schutte, N. S., \& Malouff, J. M. (2011). Emotional intelligence mediates the relationship between mindfulness and subjective well-being. Personality and Individual Differences, 50, 1116-1119.

Tedeschi, R. G., \& Calhoun, L. G. (1996). The PostTraumatic Growth Inventory: Measuring the positive legacy of trauma. Journal of Traumatic Stress, 9, 455-471.

Tedeschi, R. G., \& Calhoun, L. G. (2004). Posttraumatic growth: Conceptual foundations and empirical evidence. Psychological Inquiry, 15, 1-8.

Tedeschi, R. G., \& Calhoun, L. G. (2007). Clinical approach to growth after a traumatic experience. In P. A. Linley \& S. Joseph (Eds.), Psychologia pozytywna w praktyce [Positive psychology in practice] (pp. 230-248). Warszawa: Wydawnictwo Naukowe PWN.

Westphal, M., \& Bonanno, G. A. (2007). Posttraumatic growth and resilience to trauma: Different sides of the same coin or different coins? Applied Psychology, 56, 417-427. 